\title{
Analysis and Optimization of 4G LTE Network in Jombang City East Java
}

\author{
Widyasmoro ${ }^{* 1}$, Anna Nur Nazilah Chamim ${ }^{1}$, Rama Okta Wiyagi ${ }^{1}$, Rizkananda Muhammad Izmi ${ }^{1}$, \\ Yessi Jusman ${ }^{1}$ \\ ${ }^{1}$ Department of Electrical Engineering, Faculty of Engineering, Universitas Muhammadiyah Yogyakarta) \\ Bantul 55183 Daerah Istimewa Yogyakarta, Indonesia \\ *Corresponding author, e-mail: widyasmoro@umy.ac.id
}

\begin{abstract}
The development of communication technology in Indonesia is currently growing, one of which is cellular telecommunications technology. Cellular communication technology developed from the first generation to the present time has entered the 4th generation known as $4 G$ LTE. The writing of this final project discusses the analysis and optimization of the 4G LTE network of Telkomsel seluer operators in Jombang, East Java. Measurements were made using the drive test method to test the $4 G$ LTE network in the inner area of Jombang district. This testing is done to check the network in the inner area whether it is optimal in providing network to customers. This drive test uses a nemo handy device and to analyze drive test results using a nemo analyzer. The results measured when doing a drive test are RSRP, SNR, and throughput parameters. The results of the RSRP parameter get $95 \%$ of the total sample RSRP values $-100 \mathrm{dBm}$ to $0 \mathrm{dBm}$. The SNR parameter gets $94 \%$ of the total sample which has a value of $0 \mathrm{~dB}$ to $25 \mathrm{~dB}$. The throughput parameter gets $95 \%$ of the total sample value above $1 M b p s$. After a drive test and analysis there are 4 areas that need to be optimized because in terms of quality or SNR and the data speed or throughput is below the standards applied by the operator.
\end{abstract}

Keywords: $4 G$ LTE, RSRP, SNR, Throuhput, Drive Test

\section{Introduction}

Cellular operators that have implemented this $4 \mathrm{G}$ technology use existing sites so that the reach is still uneven. This uneven network complains that many people are ready in terms of $4 \mathrm{G}$ cellular phones. Technology that was not able to meet the desire of fast data communication. Not only that operators now have more promos on $4 \mathrm{G}$ technology but the coverage of $4 \mathrm{G}$ is still not perfect. $4 \mathrm{G}$ technology coverage is very short. The range of $4 \mathrm{G}$ itself is only able to cover an area of 500 meters to $1 \mathrm{Km}$. That's what makes the problem because of the short coverage. The selection of Jombang regency is due to the fact that this regency is often used to perform benchmark drive tests in which to compare network services between operators. The inner area of Jombang district itself has many sites installed with 4G LTE networks. The selection of TELKOMSEL operators is because this operator is one of the operators with the most users, so optimization is needed so that the users of these operators can be satisfied using the network of TELKOMSEL operators.

In this study, there are several references that become references in the analysis of 4G LTE network performance analysis. Danang, Yaqinuddin (2017) with the title Optimization and Simulation of 4G LTE Network in Yogyakarta Muhammadiyah University Area. This research aims to improve performance and provide the best solution regarding 4G LTE network problems with a case study at UMY. Optimization is done by analyzing the signal strength obtained from the drive test results, namely the RSRP, RSRQ and SINR values which are then performed physical tuning which improves the quality in the area [1].

Suko, Fajar (2017) with the title research Analysis of 4G LTE network performance in the E6 
and E7 buildings of UMY. This study uses the GNet Track Pro application by using the drive test method to determine signal quality based on RSRP, RSRQ and SINR. The results of this study found that the average RSRP value ranged from -90 to $110 \mathrm{dBm}$, then the RSRQ value ranged from -7 to $15 \mathrm{~dB}$ and the SINR value ranged from $-5 \mathrm{~dB}$ to 10 $\mathrm{dB}$. From this data it shows that the network quality in the building has not been maximized but there is still a need to improve network quality by designing and installing an indoor antenna [2].

Kusumo, Sudiarta and Ardana (2015) with the title Optimization Coverage and Analysis of LTE Service Performance of Telkomsel products in Denpasar Bali. In the Spectrum E-Journal. Vol. 2, No. 3 discussed improving the quality of LTE networks can be done by optimizing coverage and analyzing the performance of one operator in Indonesia which has a frequency of $900 \mathrm{Mhz}$. To find out the performance of Telkomsel LTE technology, a drive test cluster was conducted in the western Denpasar area by taking into account the parameters of RSRP, SINR and PDCP Througput [3].

Intan Larasati (2017) with the title "Optimization of the LTE Network in the Cigadung Area in Bandung. In writing the final project a $4 \mathrm{G}$ network data was measured in the Cigadung area. Measurements were made using the drive test method. The tool used is Nemo Handy and for analysis Nemo Analyzer is used. The parameters measured are RSRP, SINR and throughput. The results obtained are RSRP $>10 \mathrm{dBm}$, SINR $>0 \mathrm{db}$, and throughput $>12 \mathrm{Mbps}$. Liberty, Artur, Yuyun and Dennis (2017) in their writing entitled Optimization of 4G LTE Network in the North Jakarta Area. This study will explain the optimization carried out by the drive test method using nemo handy for the North Jakarta area. After the drive test analysis, there are 2 areas which are not optimal from the cellular network of PT Telkomsel that has tested the network. The parameters measured are RSRP, SINR [4].

Firdaus R, Hafidudin and Ichwan (2018) in their research journal entitled LTE Network Optimization on Jalan Utama Balikpapan City. This study aims to measure the system of the $4 \mathrm{G}$ network in the city of Balikpapan, especially in the city of Samarinda. The method used is the drive test method with a handy nemo device. Optimization here aims to get the KPI value that has been determined. An optimization simulation was performed which increased the value of the RSRP parameter by $44 \%$ and the SINR parameter $25.1 \%$ [5].
The purpose of this study is to determine the quality of $4 \mathrm{G}$ network performance, the causes of bad spots, how to optimize networks that occur in bad spot areas on $4 \mathrm{G}$ networks.

\section{Methods}

Flowchart for the research is presented in Fig. 1.

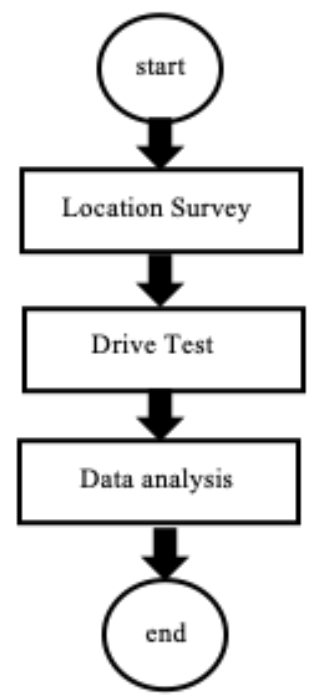

Fig. 1. Research flow chart

The steps undertaken to conduct this research can be obtained as a flow chart as follows:

1. Location Survey

The location survey is conducted to find out the terrain or geographical location that will be passed by the drive test and also to see the surrounding area that will be optimized for cellular networks. This activity is also carried out checking the sites that will be traversed and the parameters that will be tested on the location.

2. Drive Test

At this stage a drive test is carried out. Drive test is a process of measuring and retrieving $4 \mathrm{G}$ network quality data at locations in the inner area of Jombang district.

3. Analysis

At this stage an analysis of drive test results is performed. This drive test analysis aims to see which areas or locations experience both bad coverage and bad quality. This drive test analysis uses the Nemo Analyzer application. Nemo analyzer used is Nemo Analyzer version 7.2, which is used to analyze parameters related to signal level, network quality and also in terms of data speed. 


\section{Results}

\section{III.1. Drive test results RSRP (Reference Signal Received Power) Parameters}

The Figure 2 that shows the results of the drive test. The results obtained for the inner area drive test of Jombang district are said to be good network. The results of this drive test are the results of measurements on signal level strength. The results of the signal level measurement can be influenced by obstacles at the sites or during the drive test data retrieval hours.

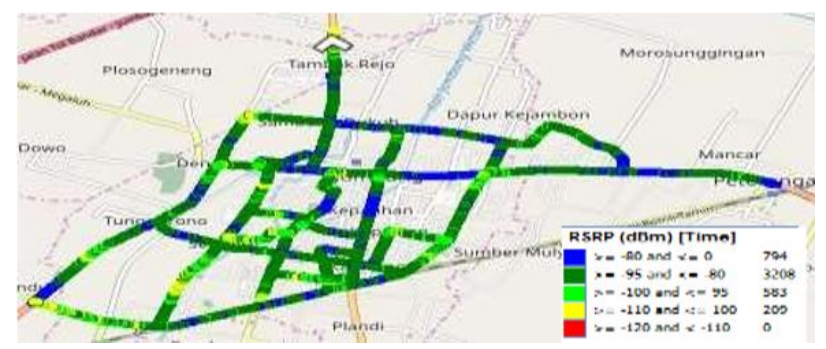

Fig. 2. Drive test results RSRP

\section{III.2. Drive test results for SINR parameters}

Judging from Figure 3, the results of the drive test in terms of quality or SINR are good. Both the poor results of the SINR drive test results can be caused by several factors, namely the value of the level of the level that was previously not good or there are sites around that interfere with network quality. The total of all drive tests with the SINR parameter looks green which means that $94.8 \%$ of the values of the SINR are valued at $0 \mathrm{~dB}$ to $25 \mathrm{~dB}$ and the remaining $5.2 \%$ which is rated at $-10 \mathrm{~dB}$ up to $0 \mathrm{~dB}$.

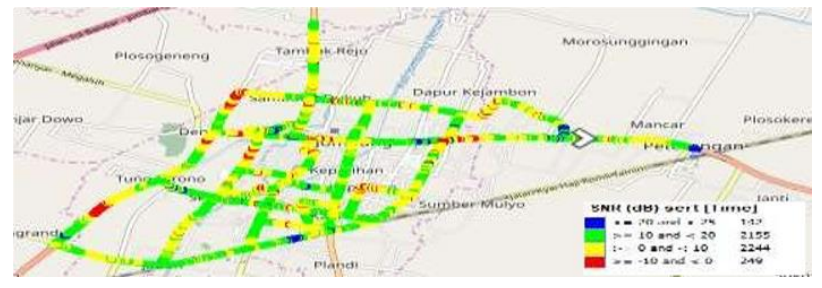

Fig. 3. Drive test results for SINR parameters

\section{III.3. Drive Throughout Parameter Test Results}

Drive test results with throughput parameters can be seen in Figure 4, that of the total map above is colored blue, which means that the drive test results are said to be good. There are some parts that are still red and along the way the colors are still mixed. Areas that are still mixed with many colors are the areas that need to be optimized. $95 \%$ of the total routes traversed by the drivet test are worth more than $1 \mathrm{Mbps}$. The remaining 5\% must be optimized to improve throughput which is still below 1 Mbps.

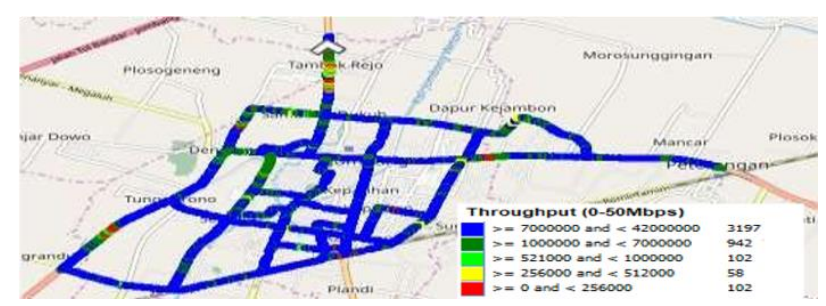

Fig. 4. Drive throughout parameter test results

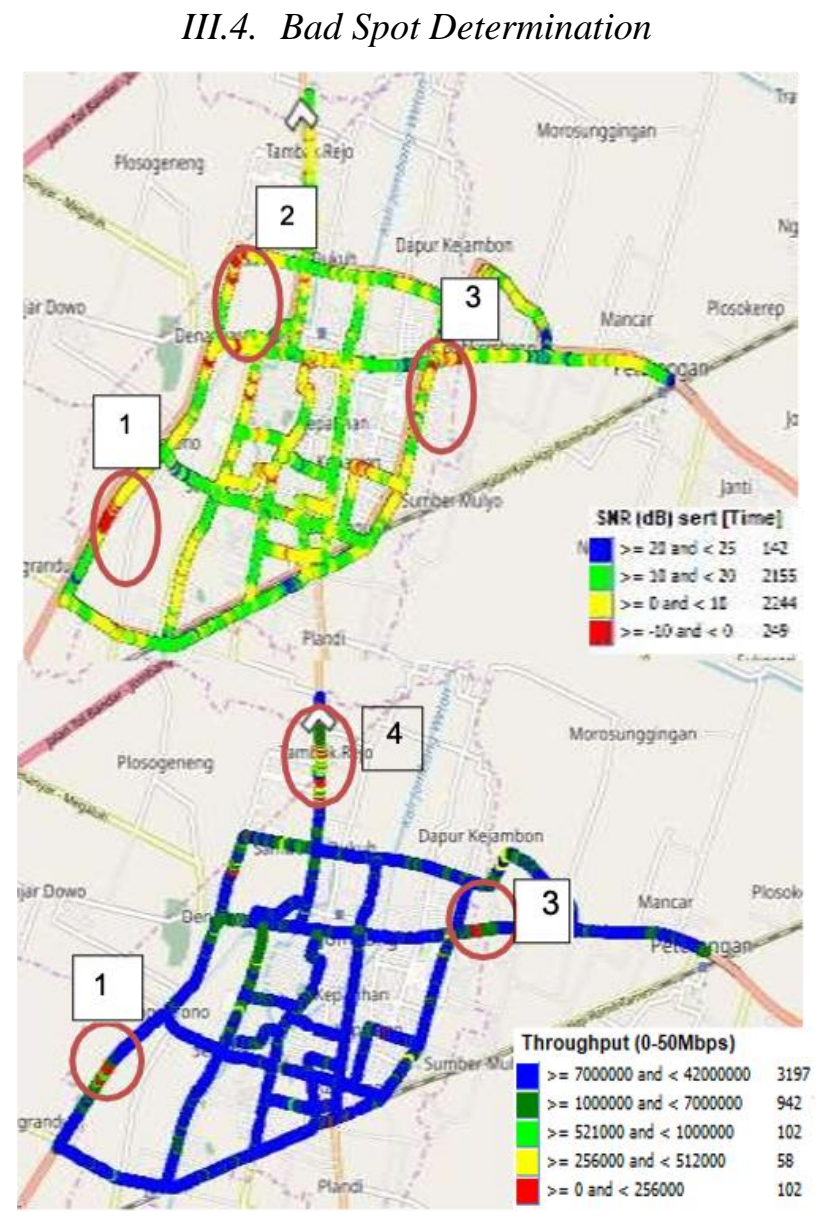

Fig. 5. Bad spot

Figure 5 are sections that are spots that have poor values of SINR and throughput parameters. There are 4 bad spots that have parameter values below the specified KPI standard.

\section{III.5. Bad Spot 1 Area Analysis (Bad SINR and Bad Throughput)}

It can be seen in Figure 6, that the parameter values in the area are bad 1. In that area, it is 
serviced by PCI 151, where the PCI is owned by distant sites and even in different districts. When serviced by PCI 151, the RSRP value is already 105 at the yellow level. In addition to serving that is far from PCI 151, which causes this area to be ugly, that is because in this area there is pilot pollution

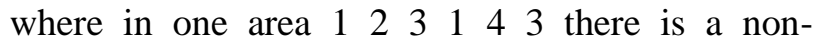
dominant RSRP value. This pilot pollution causes the SINR value or the quality of the network is bad so it results in the value of throughput.

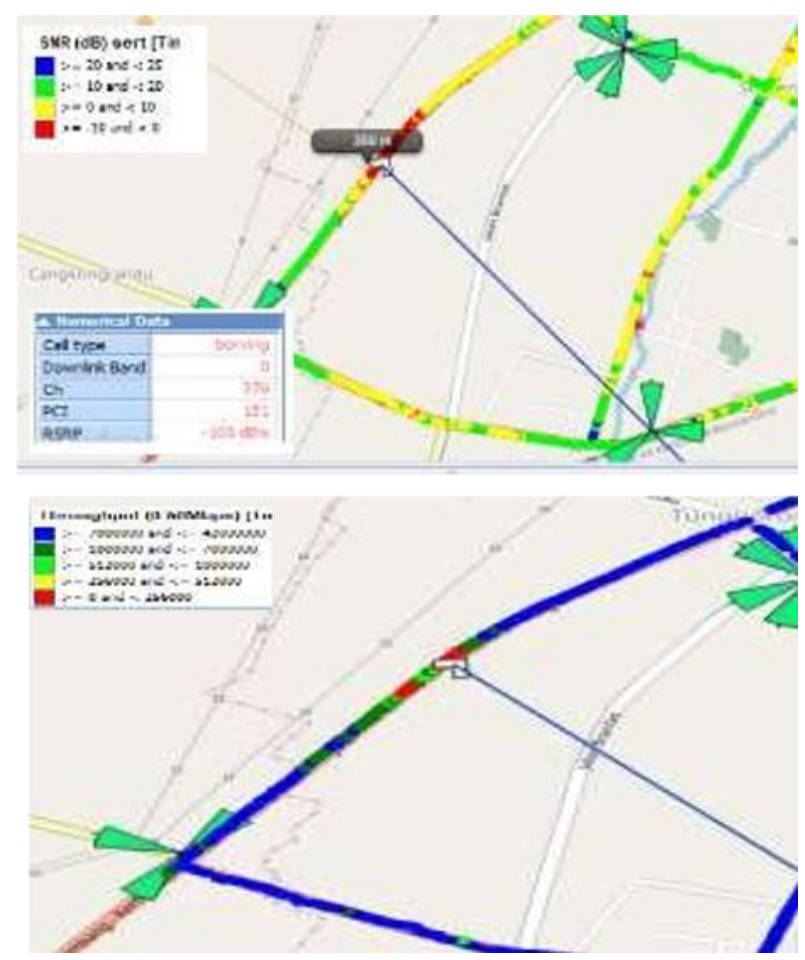

Fig. 6. Plotting Area parameter RSRP, SINR, and throughput

\section{III.6. Bad Spot 2 Area Analysis (Bad SINR)}

From Figure 7, the route included in the bad or bad area has a length of 438 meters. In this area has poor quality due to pilot pollution, ie the sites around it have RSRP values that are not much different or there is no dominant area around the route

\section{III.7. Bad Spot 3 Area Analysis (Bad SINR and Bad Throughput)}

From Figure 8, the area was chosen because the problem in this area is almost the same as bad area 1 where pilot pollution occurs because there is no dominant RSRP value even though there is one cell serving in that area, but the serving is not from the closest site. Resulting in the quality of getting red color and also have an impact on the throughput parameters.
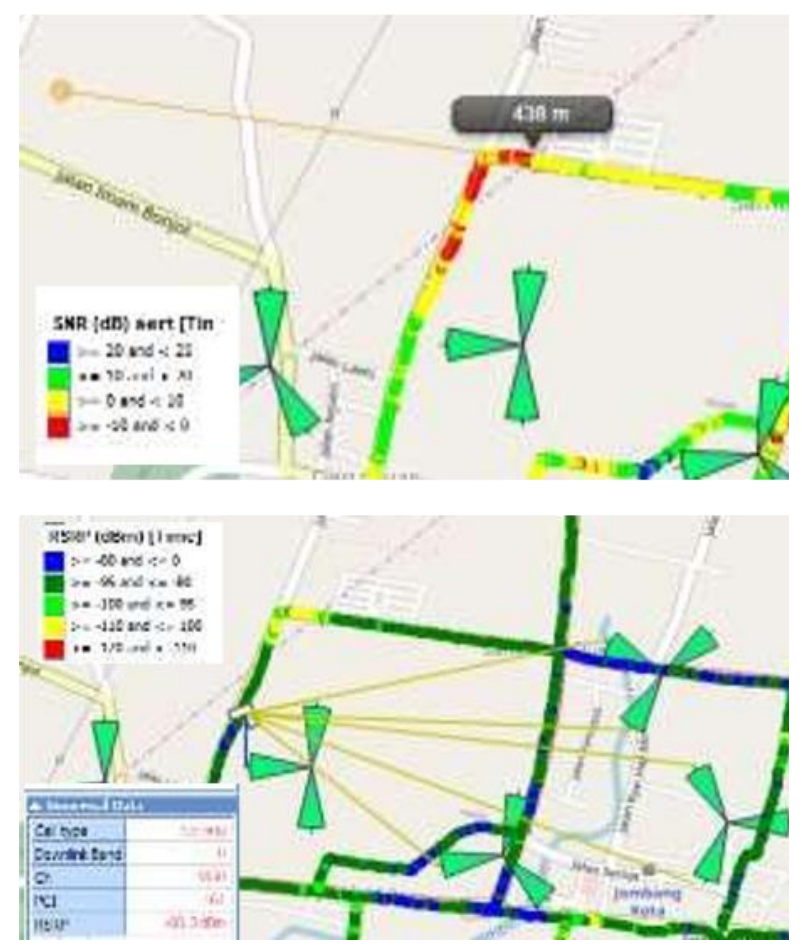

Fig. 7. Spot 2 the bad SINR

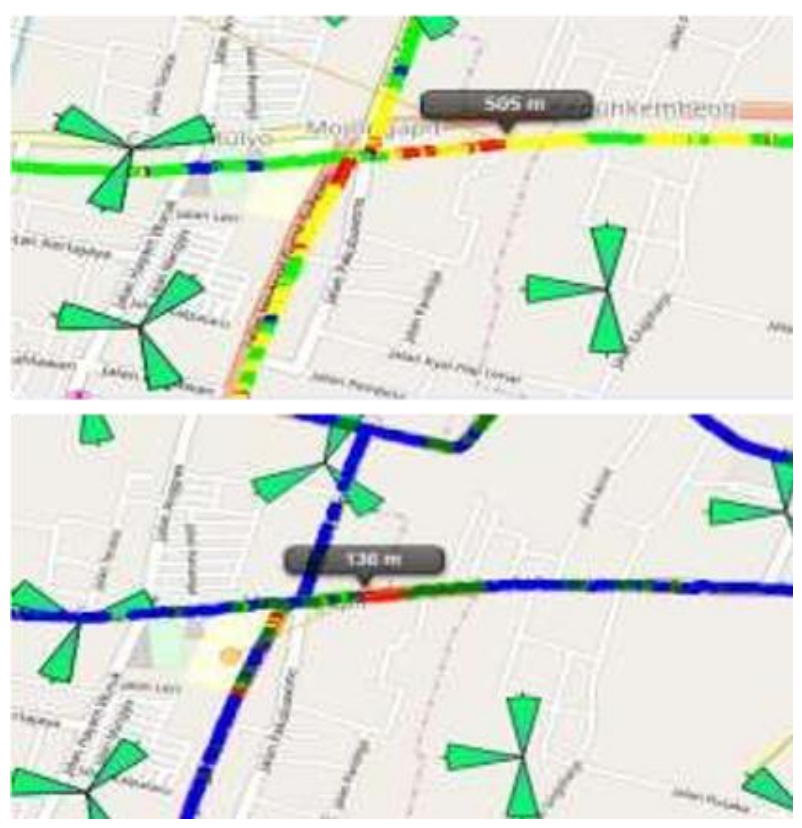

Fig. 8. Spot 3 the bad SINR

\section{III.8. Bad Spot 4 Area Analysis (Bad Throughput)}

From Figure 9, it can be seen that the length of the problematic route is 433 meters. This bad spot is due to the area getting seving from the nearest side loob site. The analysis of this software sees that the 
route is sorted by pci 30 . The RSRP and SINR parameters have good values but the throughput parameters are still lacking.
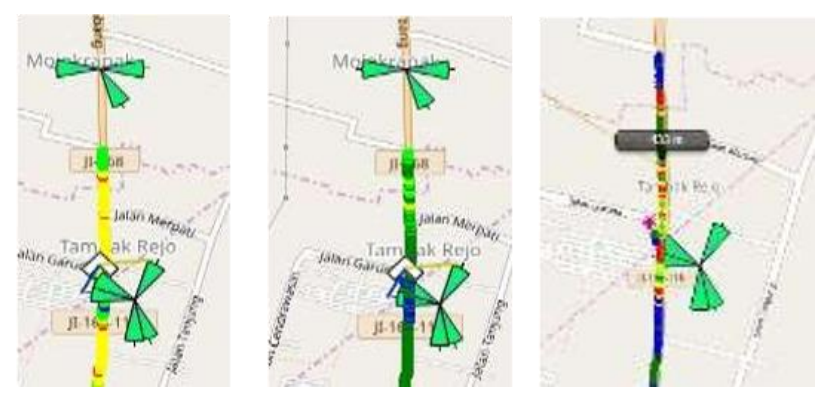

Fig. 9. Bad spot 4 area analysis (bad throughput)

\section{III.9. Spot Optimization 1}

After the analysis of bad spots in area 1 that have quality problems that have an impact on access speed or throughput. The method used in this area is to use both methods, namely using physical and non-physical. The steps that must be taken to optimize this area are:

1. Ensuring the site is in good condition by looking at KPIs from serving or closest sites through software.

2. Seeing TA (Timing Advance) or the distribution of customers from serving sites whether exceeding neighboring sites.

3. For areas that are over-shot from other districts, the RS (Reference Signal) power is reduced from the serving site.

4. Eliminating pilot pollution in areas that are not well done by dominating the area.

5. The method of dominating is tilting on a sectoral antenna facing the route area.

6. Reducing the RS (Reference Signal) power from nearby sites so as not to cause pilot pollution.

\section{III.10. Spot Optimization 2}

Optimization on spot 2 is still not good on the drive test route. At this spot, the quality is not good, but it does not affect the results of the data speed. The optimization method for this area uses nonphysical methods by means of optimization with parameters. The steps to do the optimization are:

1. Look at the KPI from the radio side whether there are problems in the serving site. If there is a problem it must be done through software.

2. To reduce or increase the RS power at the site so that the area becomes dominant from the closest site.
3. Seeing TA (Timing Advance) or the distribution of customers from sites serving whether over shoot.

4. Do a retest drive. This is done because it could be done by re-testing the area can be back to normal.

\section{III.11. Spot Optimization 3}

After the analysis of bad spots in area 3 that have quality problems that have an impact on access speed or throughput. Then the optimization is done so that the spot becomes according to KPI standards. The method used in this area is by tilting the antenna. The steps that must be taken to optimize this spot are:

1. Make sure the site is in good condition by looking at KPIs from serving or closest sites through software.

2. Seeing TA (Timing Advance) or the distribution of customers from serving sites whether exceeding neighboring sites.

3. Eliminating pilot pollution in areas that are not well done by dominating the area.

4. The method of dominating is tilting on a sectoral antenna facing the route area.

\section{III.12. Spot Optimization 4}

Spot 4 has spots where the value of the throughput parameter is still not good. So that the spot 4 route gets a good throughput value, optimization is performed so that this area becomes optimal. The method used in optimizing this area is the physical method by rotating the azzimuth direction. Steps taken for this area are:

1. Ensuring the site is in good condition by looking at KPIs from serving or closest sites through software.

2. Seeing TA (Timing Advance) or the distribution of customers from serving sites.

3. Shifting the sectoral direction to the area that is not optimal because the area gets a side loob, not getting serving from the main loob.

\section{Conclusion}

Based on the test results of the inner drive area test data of Jombang district, East Java, some conclusions can be drawn as follows: The average RSRP value on Malioboro Street is worth - 86.4 $\mathrm{dBm}$. This value if shown based on the KPI standard in G-Net Track Pro is in the range of -80 $\mathrm{dBm}$ to $-90 \mathrm{dBm}$ in good condition. 
1. The results of the drive test on the Jombang inner route still have 4 parts of the route that must be optimized.

2. The results of the RSRP parameter are $95.6 \%$ of the total sample that has a RSRP value of $100 \mathrm{dBm}$ to $0 \mathrm{dBm}$.

3. The SINR parameter gets $94.8 \%$ of the total sample that has the SINR is rated $0 \mathrm{~dB}$ to 25 $\mathrm{dB}$.

4. The throughput parameter gets $95 \%$ of the total sample on the route through the drivet test valued above 1 Mbps.

5. The entire route is serviced by the LTE system because the method used is the LTE lock.

6. Overall the results of the drive test are said to be good because the parameter values are above the applied KPI standard

\section{Acknowledgements}

This work was supported by Universitas Muhammadiyah Yogyakarta.

\section{References}

[1] D. Y. Haq, "Optimasi dan Simulasi Jaringan 4G LTE diarea Universitas Muhammadiyah Yogyakarta," Universitas Muhammadiyah Yogyakarta, 2017.

[2] F. Suko, "Analisis Performansi Jaringan 4G LTE di Gedung E6 dan E7," Universitas Muhammadiyah Yogyakarta, 2017.

[3] V. S. Kusumo, P. K. Sudiarta, and I. P. Ardana, "ANALISIS PERFORMANSI DAN OPTIMALISASI COVERAGE LAYANAN LTE TELKOMSEL DI DENPASAR BALI," $J$. SPEKTRUM; Vol 2 No 3 J. SPEKTRUM.

[4] I. Larasati, Hafidudin, and F. Rizkiatna, "Optimasi Jaringan LTE di Area Cigadung Bandung," $e$ Proceeding Aplied Sci., vol. 3, no. 3, pp. 2036-2043, 2017.

[5] R. Firdaus, Hafidudin, and S. Ichwan, "Optimasi Jaringan LTE di Jalan Utama Area Balikpapan Utara," e-Proceeding Appl. Sci., vol. 4, no. 2, pp. 541-550, 2018.

\section{Authors' information}

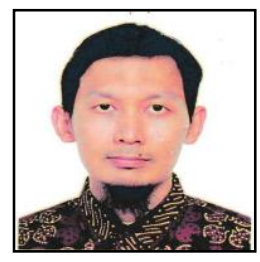

Widyasmoro obtained his B. Eng in Electrical Engineering from Universitas Jenderal Soedirman, Indonesia in 2007. His Master study was done at 2009 at the Electrical Engineering, Asia University, Taiwan. He currently is a lecture in department of electrical engineering, Universitas Muhammadiyah Yogyakarta.

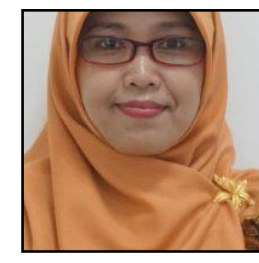

Anna Nur Nazilah Chamim obtained her B. Eng in Electrical Engineering from Universitas Muhammadiyah Yogyakarta, Indonesia. Her Master study was done at 2015 at the Electrical Engineering, Universitas Gadjah Mada, Indonesia. She currently is a lecture in department of electrical engineering, Universitas Muhammadiyah Yogyakarta.

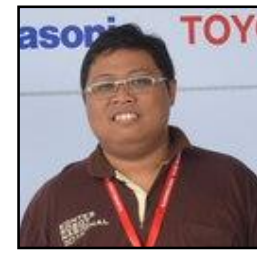

Rama Okta Wiyagi obtained his B. Eng in Electrical Engineering from Universitas Muhammadiyah Yogyakarta, Indonesia in 2009. His Master study was done at 2015 at the Electrical Engineering, Universitas Gadjah Mada, Indonesia. He currently is a lecture in department of electrical engineering, Universitas Muhammadiyah Yogyakarta.

Rizkananda Muhammad Izmi obtained his B. Eng in Electrical Engineering from Universitas Muhammadiyah Yogyakarta, Indonesia in 2018

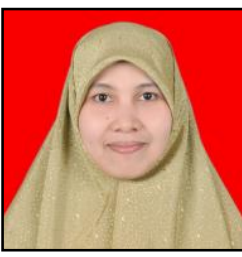

Yessi Jusman obtained her B. Eng in Electrical and Electronic Engineering from Andalas University, Indonesia in 2007. She worked as a Research Assistant started in July 2008 until November 2009 in Universiti Sains Malaysia. Her Master study was done at 2012 at the School of Electrical and Electronic Engineering, USM Engineering Campus in Nibong Tebal, Penang, Malaysia. She was finished her $\mathrm{PhD}$ degree at 2016 in University of Malaya with specializes in Image, Signal Processing, and algorithms. She currently is a lecture in department of electrical engineering, Universitas Muhammadiyah Yogyakarta. 